\title{
The impact of digital currency on the activities of digital platforms
}

\author{
Tuyana B. Zambalaeva ${ }^{1, *}$, Chen Yang $^{2}$ \\ ${ }^{1}$ Institute of Economics and Management of National Research Tomsk State University, Tomsk, \\ Russia \\ ${ }^{2}$ Institute of Credit Theory and Financial Management of Saint Petersburg State University, Saint \\ Petersburg, Russia
}

\begin{abstract}
The article discusses the impact of digital currency on the activities of platform companies. Companies use digital platforms to improve their efficiency, build relationships between customers and the company itself, while reducing costs. The aim of the work is to determine the prospects for digital currency both on platforms and in the financial sector. It was determined that digital currencies guarantee a secure payment environment for transactions, the cost of creating the currencies themselves is low in relation to paper banknotes. Hence, the introduction of a digital currency could bring about fundamental changes in the architecture of many areas.
\end{abstract}

\section{Introduction}

Research in digital technology is a popular area of research in the scientific community. Currently, the concept of "digital technology" "digital currency" "digital platforms" and other digital phenomena have not fully researched.

For example, large tech companies Microsoft, Amazon, Alibaba Apple, Google and Facebook use digital platforms. The most common types of platforms are transactional platforms that match supply and demand (e.g. Amazon, Alibaba, Airbnb, and Uber). Other examples are technology platforms that provide the technical infrastructure (for example, the Microsoft software platform and the Google and Apple app stores). [1] These digital platforms have radically changed the way we work, communicate, learn and produce.

Scope platform is quite extensive, ranging from training (Coursera, EdX, Udacity and FutureLearn) and to the smart home (eg, Amazon Alexa, Apple Homekit, Google Assistant, Philips Hue and Samsung). Platform development is relevant because it combines new business models with technological innovations.

\footnotetext{
* Corresponding author: zambalayeva@ mail.ru
} 


\section{Platform ecosystem elements}

The platform-based ecosystem consists of two main elements - the platform and additional applications. Applications are additional products for platforms. Two products complement each other when one increases the attractiveness of the other. Consequently, the platform consists of core technologies and a common infrastructure that applications can use. Applications access the platform functionality and use it through a set of interfaces that allow them to interact with the platform. A set of platforms and applications that interact with it creating an ecosystem of the platform.

Outside of these central elements of the platform ecosystem are the following features: end users, competing platforms and the competitive environment in which they exist.

In a platform ecosystem, there is an internal competitive environment, often competing with other platform systems.

Cohesion platform promotes activity that dominates all others. Payment is key point e for such an activity on many platforms. All other actions on the platform are also dependent on the payment, the activity generated by the payment. Therefore, payment functionality is crucial for the platform's value and growth.

Regular payment make through a digital platform through third parties such as Alipay, WeChat Pay in China and eBay. After using the digital currency of the central bank, the cost of government services is borne by the state at the expense of the financial burden, which reduces the security of expenses of individuals and SMEs using digital payment tools. Moreover, higher than that of third-party commercial payment instruments, but also more conducive to popularization in areas with relatively backward infrastructure. It can also reduce the cost of using the capital of SMEs.

Digital currency payment can provide the minimum guarantee function for the transaction environment. The secure payment environment makes transactions free of risks, which helps to meet the payment needs of small platforms, and the circulation of funds through the central bank is more convenient for unified national management

Consider a bank evaluating a loan applicant, for example. If the bank has access to a payment platform's data, it could track the applicant's income and payments, including data on the frequency, location, and nature of purchases.

In general, would enable the bank to estimate the probability of repayment with great precision, far exceeding the predictive accuracy of the applicant's credit score. Payment data generated by platforms are, in fact, an ideal predictive tool for users' preferences and behavior.

\section{Digital currencies}

Digital currencies are a new direction in the development of modern financial systems. The first digital currency offered was Bitcoin, offered by Satoshi Nakamoto in November 2008.[2] This is a cryptocurrency based on P2P and a decentralized payment system. The biggest difference with other virtual currencies is that there are very few of them. It does not depend on the issuance of specific currency institutions, but is generate by a large number of settlements in accordance with specific algorithms.

The number of Blockchain wallets has been growing since the creation of the virtual currency Bitcoin in 2009, reaching over 50 million Blockchain wallet users at the end of June 2020.

Consider the recommendations and proposals of Bank for International Settlements (BIS) on digital currencies.

In November 2015, the Bank for International Settlements (BIS) published the Digital Currencies report, which details the impact of digital currency on retail payments [3]. In June 
2017, the International Monetary Fund (IMF) published a report, Fintech and Financial Services: Initial Considerations for the Development of the Fintech Industry [4].

In March 2018, the Bank for International Settlements issued a "Digital Currency Pair of the Central Bank". The report "The Impact of Central Bank Digital Currency on Payment, Monetary Policy, and Financial Stability" analyzes the issue of digital currency of the central bank [5].

In 2018, the Organization for Economic Cooperation and Development (OECD) and the G20 jointly released an interim report "Tax Challenges Brought to Digitalization," which proposed to monitor information about transactions with digital assets generated using cryptocurrencies and blockchain technology.

In January 2020, the Bank for International Settlements conducted a survey of 66 central banks, and about $20 \%$ of central banks said they could issue digital currencies over the next six years.

Since 2014, digital currency in China gradually developed. The history of development as bellow (Table 1).

Table 1. Digital currency development in China.

\begin{tabular}{|c|c|}
\hline Year & Events \\
\hline 2014 & $\begin{array}{l}\text { China's central bank set up a special research group on digital } \\
\text { currency and began to study digital currency }\end{array}$ \\
\hline 2015 & $\begin{array}{l}\text { With the further exploration of digital currency issuance and } \\
\text { business operation framework, development technology, a } \\
\text { series of digital currency research reports were released }\end{array}$ \\
\hline 2016 & $\begin{array}{l}\text { The central bank's goal of issuing digital currencies to the } \\
\text { public, and openly recruiting digital currency related R\&D } \\
\text { technical talents on the official website for the first time }\end{array}$ \\
\hline 2017 & $\begin{array}{l}\text { The Digital Currency Research Institute was officially } \\
\text { established, and the blockchain-based digital bill trading } \\
\text { platform promoted by the central bank was successfully tested }\end{array}$ \\
\hline 2018 & $\begin{array}{l}\text { In March, the People's Bank of China held the } 2018 \text { National } \\
\text { Currency Gold and Silver Work Video and Telephone } \\
\text { Conference. The meeting pointed out that "steadily promoting } \\
\text { the central bank's digital currency research and development"; } \\
\text { in August, the State Council said in a statement that it supports } \\
\text { the development of innovative applications such as digital } \\
\text { currency research and mobile payment in Shenzhen }\end{array}$ \\
\hline 2019 & $\begin{array}{l}\text { In February, the National Currency, Gold and Silver Working } \\
\text { Conference of the People's Bank of China mentioned "steady } \\
\text { and in-depth" promotion of central bank digital R\&D. In } \\
\text { October, the National President stated "blockchain should be } \\
\text { used as an important breakthrough in independent innovation of } \\
\text { core technology." The central bank's legal digital currency is } \\
\text { basically mature in terms of technology and operating } \\
\text { framework }\end{array}$ \\
\hline 2020 & $\begin{array}{l}\text { China's "Cryptography Law", which came into effect on } \\
\text { January 1st, aims to "promote the development of encryption }\end{array}$ \\
\hline
\end{tabular}




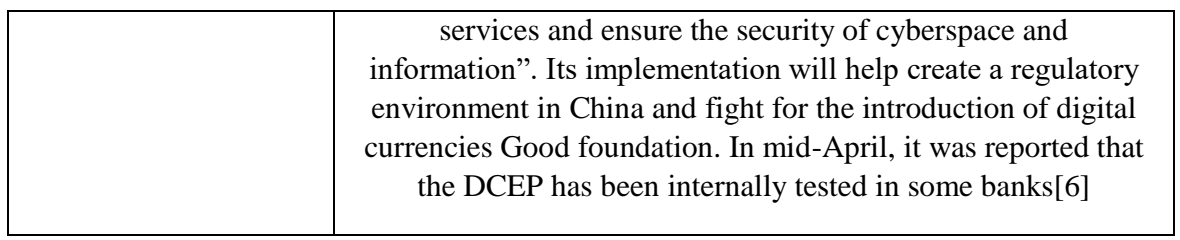

Unlike Bitcoin, the central bank's digital currency is centralized. The central bank issues and controls from the outside. The biggest advantage is that the bank acts as a lender, and its function is the same as paper money, but this is a digital form. Bank deposits and payment account balances are electronic forms of legal tender.

The three generally existing forms are cash, bank deposits and payment account balances. Digital currency replaces M0 (cash in circulation) instead of M1 (M1 = M0 + demand deposit), M2 (M2 = M0 + fixed deposit). Payment account balances is the electronic payment tools such as Alipay and WeChat Pay and others, they are essentially electronic forms of legal tender, not new currencies.

In the existing retail payment system, the ultimate source of funds is bank deposits and payment account balances. Therefore, digital currency will not cause a major impact on other electronic payment tools. After the launch of digital currency, China's currency system is to complement each other with banknotes, digital currency, and electronic payment.

Therefore, compared to paper currency, digital currency can say that it represents a trend. In the future, whether in life or on national exchanges, the digital currency will become the main one in trading life. Its advantages are obvious:

1. Saving the cost of cash flow. As we all know, the cost of issuing and restoring, storing and protecting banknotes is high, and carrying banknotes is inconvenient. In contrast, the cost of the issue is very low and not be faked, therefore can satisfy the demand for this payment.

2. Digital currency is legal tender approved by the government and guaranteed by a central bank loan. Strengthening the payment system can lead to the promotion of inclusive finance, ensuring the reliability of financial transactions, and toughening the control of the currency circulation market.

3. Since information between various banks and electronic money not transmitted, it is impossible track the whole process of cash circulation as well as money laundering and legalize financing. Digital currency combined with big data, artificial intelligence, account monitoring, etc., the circulation process is completely transparent and monitored, which can increase the effectiveness of financial supervision.

However, the digital currency also has potential risks such as weakening the initial credit and profitability of commercial banks, and more easily triggering systemic financial risks.

Thus, by 2019 the legal digital currency of the central bank will become mature in terms of technology and operating structure. It is expect that in 2020, despite the twofold impact of the epidemic and economic downturn, the central bank's digital currency will accelerate its landing and provide a new round of the Chinese financial market.

\section{Conclusion}

As a conclusion, we state that digital platforms issue currencies to improve the business model, grow the ecosystem of partners and thereby increase profits. Central banks and other government bodies study and control these innovations on the platform for a number of reasons. Firstly, digital currencies are innovations that can increase the efficiency of retail payments, for example, by providing a cheaper, faster or more convenient alternative to existing payment methods, especially for online transactions. Secondly, digital currencies can raise a range of public policy and regulatory issues if they become a widely used means 
of payment. Furthermore, the existing platform payment methods will not change, and the basic framework and pattern of the current payment market will not undergo major changes, but will continue to developing.

\section{References}

1. A. Rangaswamy, N. Moch, C. Felten, et al. The Role of Marketing in Digital Business Platforms, Journal of Interactive Marketing, https://doi.org/10.1016/j.intmar.2020.04.006 (2020)

2. Nakamoto S, Bitcoin: A Peer-to-Peer Electronic Cash System (2008)

3. Bank for International Settlements, Digital currencies. Retrieved from https://www.bis.org/ (2015)

4. He D. Fintech and Financial Services: Initial Considerations. IMF, 5, 17 (2017)

5. Bank for International Settlements. Central bank digital currencies. Retrieved from https://www.bis.org/ (2018)

6. Ying Z. Digital currency may be issued, which is expected to continue to empower the current financial system. Orient Securities, 13 (2020)

7. Dulatova N., Hakim A., Razak A. The Ecosystem of Cryptocurrency as an Object of Civil Rights in BRICS Countries, BRI CS Law Journal, 7(2), 37-65 (2020).

8. Jocevskia M, Ghezzib A, Arvidssona N Exploring the growth challenge of mobile payment platforms: A business model perspective. Electronic Commerce Research and Applications, 13 (2020) 